\title{
Blossom-end rot: a century-old problem in tomato (Solanum lycopersicum L.) and other vegetables
}

\author{
Yasin Topcu', Savithri U. Nambeesan ${ }^{2}$ and Esther van der Knaap ${ }^{1,2^{*}}$ (i)
}

\begin{abstract}
Blossom-end rot (BER) is a devastating physiological disorder affecting vegetable production worldwide. Extensive research into the physiological aspects of the disorder has demonstrated that the underlying causes of BER are associated with perturbed calcium $\left(\mathrm{Ca}^{2+}\right)$ homeostasis and irregular watering conditions in predominantly cultivated accessions. Further, Reactive Oxygen Species (ROS) are critical players in BER development which, combined with unbalanced $\mathrm{Ca}^{2+}$ concentrations, greatly affect the severity of the disorder. The availability of a high-quality reference tomato genome as well as the whole genome resequencing of many accessions has recently permitted the genetic dissection of BER in segregating populations derived from crosses between cultivated tomato accessions. This has led to the identification of five loci contributing to BER from several studies. The eventual cloning of the genes contributing to BER would result in a deeper understanding of the molecular bases of the disorder. This will undoubtedly create crop improvement strategies for tomato as well as many other vegetables that suffer from BER.
\end{abstract}

Keywords: Blossom-end rot (BER), Reactive Oxygen Species (ROS), $\mathrm{Ca}^{2+}$ deficiency, Abiotic stress, Cell wall, Tomato, Antioxidants, Plant growth regulators, Fruit morphology

\section{Introduction}

Vegetable production is challenged by a range of biotic and abiotic factors, often resulting in a substantial loss of the produce in each growing cycle. As the population is growing, the world is facing increasing demands for a stable food supply grown on agricultural lands across the globe. Unfortunately, abiotic stresses are becoming increasingly more prevalent especially in light of climate change. Climaterelated changes, which are exemplified by extreme air and water temperature, increased frequency and intensity of rainfall, intense hurricanes and so forth are becoming more prevalent (Wuebbles et al. 2017; Hoegh-Guldberg et al. 2018; U.S. Environmental Protection Agency 2021).

\footnotetext{
* Correspondence: EsthervanderKnaap@uga.edu

${ }^{1}$ Institute of Plant Breeding, Genetics and Genomics, University of Georgia, Athens, GA 30602, USA

${ }^{2}$ Department of Horticulture, University of Georgia, Athens, GA 30602, USA
}

Undoubtfully, these extreme weather events will lead to an increase in stress related diseases and disorders (U.S. Global Change Research Program 2009). Short, and long-term impacts of climate change are expected to further increase these extreme weather conditions; thus, the stability of food supplies and crop productivity will continue to be affected adversely from these extreme events (Motha and Baier 2005; U.S. Global Change Research Program 2009; Lobell et al. 2013; Hoegh-Guldberg et al. 2018).

$\mathrm{BER}$ is one of the most devastating physiological disorders that affect various crops such as tomato (Solanum lycopersicum L.), pepper (Capsicum annuum L.), watermelon (Citrullus lanatus (Thunb.) and eggplant (Solanum melongena L.) (Taylor and Locascio 2004; Díaz-Pérez and Hook 2017) (Fig. 1). A related disorder in apple is bitter pit (Bangerth 1979; de Freitas et al. 2010), BER and related disorders affect mostly the fruit, but other organs such as

C C The Author(s). 2022 Open Access This article is licensed under a Creative Commons Attribution 4.0 International License, which permits use, sharing, adaptation, distribution and reproduction in any medium or format, as long as you give appropriate credit to the original author(s) and the source, provide a link to the Creative Commons licence, and indicate if changes were made. The images or other third party material in this article are included in the article's Creative Commons licence, unless indicated otherwise in a credit line to the material. If material is not included in the article's Creative Commons licence and your intended use is not permitted by statutory regulation or exceeds the permitted use, you will need to obtain permission directly from the copyright holder. To view a copy of this licence, visit http://creativecommons.org/licenses/by/4.0/ The Creative Commons Public Domain Dedication waiver (http://creativecommons.org/publicdomain/zero/1.0/) applies to the data made available in this article, unless otherwise stated in a credit line to the data. 

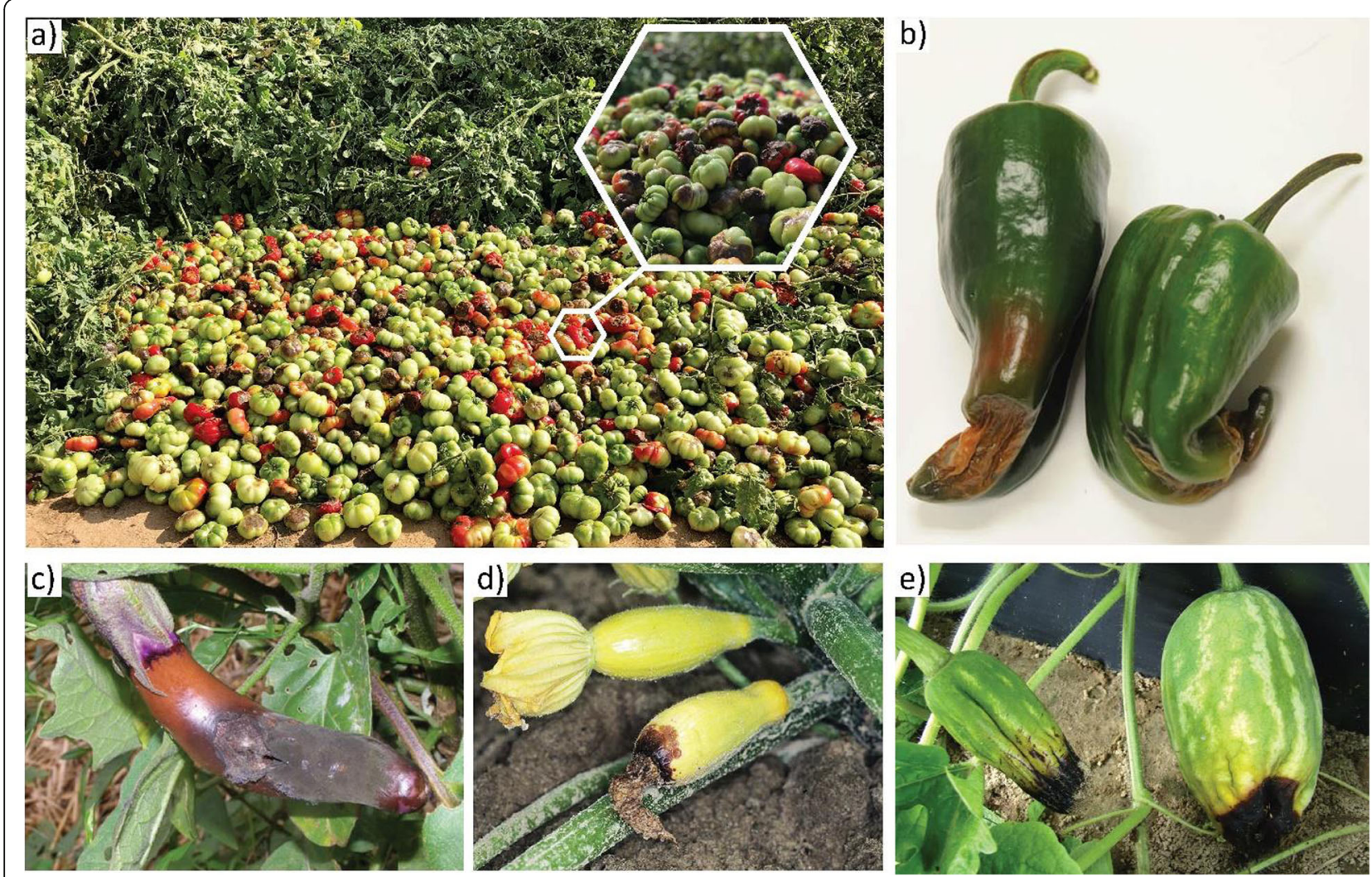

Fig. 1 Blossom-end rot in various fruit and vegetable crops. a) BER in tomato. b) BER in pepper, image credit (WSU NWREC, 2021). c) BER in eggplant, image credit (University of Minnesota Extension, 2021). d) BER in squash, image credit (Voyle, 2021). e) BER in watermelon, image credit (UF/IFAS, 2021)

leaves, and flowers can suffer as well. Various leafy vegetables suffer tipburn (Kuo et al. 1981; Francois et al. 1991; Barta and Tibbitts 2000; Macias-González et al. 2019; Su et al. 2019) and other vegetables such as celery and cauliflower are affected by disorders that appear similar to BER (Geraldson 1952; Rosen 1990; Bouzo et al. 2007; Bianco et al. 2015). Combined, these physiological disorders can lead to significant yield losses especially in subsistence and organic farming (Ikeda and Kanayama 2015; Hagassou et al. 2019). As the demand for organic produce is increasing, the impact of abiotic stresses on this sector may become substantial as well. As an example, Hickory Hill Farm in Carlton GA, USA faced a challenging season in 2018 when they lost almost $80 \%$ of the organically grown tomatoes to BER (Josh Johns and Gary Shaw, personal communication). BER was first described in tomato more than 120 years ago as a physiological disorder caused by inconsistent watering (Selby 1896), a notion that has held up until today. The early studies also indicate that BER is of great concern as it was linked to significant crop losses caused by canopy transpiration rate and the use of ammonium-based fertilization (Stuckey 1916; Wedgworth et al. 1927; Chamberlain 1933).
In this review, we summarize the recent findings on the development of BER from research primarily conducted in tomato. These findings are starting to shed light on the molecular basis of the onset of BER as well as crop improvement strategies that can be applied in the near future.

\section{Development of BER symptoms}

The initial external symptoms of BER in tomato are often observed on the distal portion of the fruit during the second week after pollination but can also occur later during development at five weeks after pollination (Spurr 1959; Marcelis and Ho 1999; Saure 2001; Ho and White 2005; de Freitas et al. 2018; Rached et al. 2018). Typical symptoms appear as small light colored, water soaked spots on the blossom end of the fruit which is associated with cell plasmolysis and leaky membranes (Ho and White 2005) (Fig. 2). BER symptoms usually appear externally on the pericarp at the distal end, but affected areas may also occur in the internal distal placenta tissue without visible external symptoms (Brust 2004; Hochmuth and Hochmuth 2009). After BER induction, BERaffected areas often expand and turn into brown necrotic 


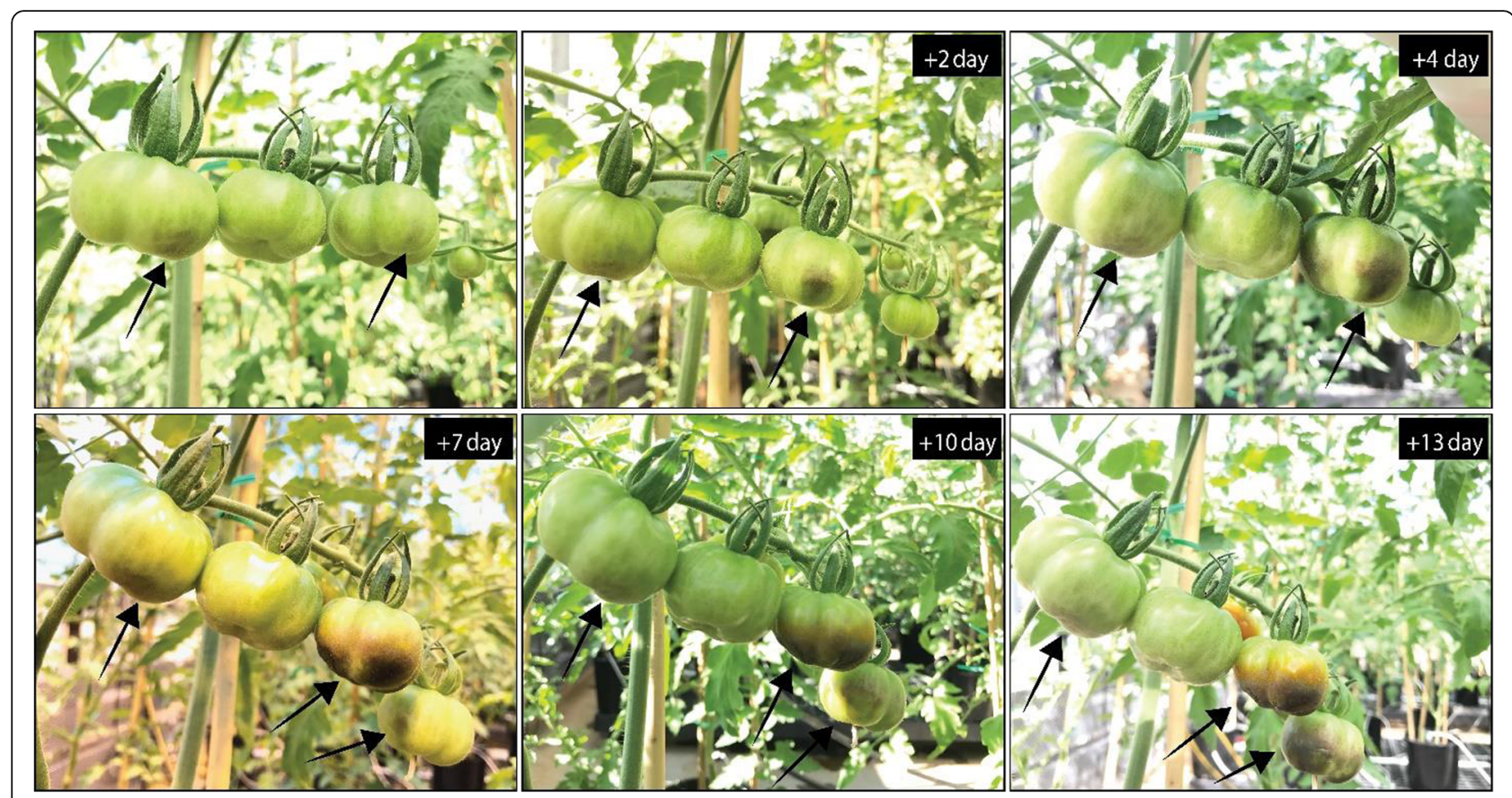

Fig. 2 BER development in four fruits on one inflorescence. After first BER appearance was observed (top left panel), subsequent images were taken at time intervals in days from the initial image. Arrows indicate BER afflicted fruits. The BER on the first fruit did not expand to the entire fruit whereas the last fruit is consumed by BER in a short period of time

regions covering a significant proportion of the fruit and in some extreme cases affect the entire fruit. Occasionally, BER fails to expand, and the afflicted areas disappear. The symptoms can be exacerbated if they occur soon after pollination and, in such cases, the fruit never attains its maximum size. BER-afflicted areas often become prone to invasion from secondary pathogens such as saprophytic Alternaria fungal species (Brust 2004; Hochmuth and Hochmuth 2009).

\section{Relationship between $\mathrm{Ca}^{2+}$ and BER}

Findings from many studies have suggested that $\mathrm{Ca}^{2+}$ deficiency initiates BER incidence (Shear 1975; Adams and Ho 1993; Taylor and Locascio 2004; de Freitas et al. 2012b; Watanabe et al. 2021). During fruit growth, the differential $\mathrm{Ca}^{2+}$ concentrations between the proximal (high) and distal (low) end of the fruit is correlated to the appearance of BER such that the higher the difference, the higher incidence of BER (Franco et al. 1994). $\mathrm{Ca}^{2+}$ plays an essential role in plant growth and development where it fulfills three main functions. $\mathrm{Ca}^{2+}$ acts a secondary messenger (Kudla et al. 2010; Thor 2019), and the subcellular concentration in the cytosol, vacuole and apoplast are tightly regulated by $\mathrm{Ca}^{2+}$-ATPases, $\mathrm{H}^{+} / \mathrm{Ca}^{2+}$ exchangers, and channel proteins at different cellular membranes (Clarkson et al. 1993; Clapham 2007; Kudla et al. 2010; Thor 2019). Second, $\mathrm{Ca}^{2+}$ has a structural role in determining the rigidity of the cell wall through cross-linking with the de-esterified pectin in the middle lamella (Micheli 2001; Hepler and Winship 2010; Thor 2019). The largest $\mathrm{Ca}^{2+}$ pool of at least $60 \%$ is localized to the cell wall (Demarty et al. 1984). And third, free apoplastic $\mathrm{Ca}^{2+}$ concentration maintains the cell membrane integrity through connecting the phospholipids and proteins at the plasma membrane (Hepler and Winship 2010; Marschner 2011; Thor 2019). $\mathrm{Ca}^{2+}$ in BER development is associated with the aberrant regulation of its partitioning and distribution in different cellular compartments. For instance, apoplastic $\mathrm{Ca}^{2+}$ concentration specifically in the distal end of the fruit, rather than total $\mathrm{Ca}^{2+}$ concentration in the distal part, are negatively correlated to BER development (Ho and White 2005; de Freitas et al. 2011b). $\mathrm{Ca}^{2+}$ homeostasis can be perturbed by expression of Arabidopsis $s C A X 1$ (Cation Exchanger 1), encoding a functional $\mathrm{Ca}^{2+} / \mathrm{H}^{+}$antiporter in tomato. $s C A X 1$ encodes a $\mathrm{N}$-terminal truncated version of the fulllength gene that does not contain its regulatory region and therefore is constitutively active. When $s C A X 1$ is expressed in tomato, $100 \%$ of the fruit exhibited BER symptoms (Park et al. 2005; de Freitas et al. 2011b). The $s C A X 1$ tomato exhibited higher total water soluble and fruit $\mathrm{Ca}^{2+}$ concentrations compared with the control. However, $s C A X 1$-expressing tomato plants increased the transport of $\mathrm{Ca}^{2+}$ from the cytosol to the vacuole resulting in lower cytosol and apoplast $\mathrm{Ca}^{2+}$ concentration compared to non-transformed control. These results support 
the notion that altered $\mathrm{Ca}^{2+}$ homeostasis among different cellular compartments interferes with the signaling cascade that orchestrates the induction of downstream responses to BER or prevent BER from happening altogether (de Freitas et al. 2011b). The altered $\mathrm{Ca}^{2+}$ distribution is proposed to disrupt the integrity and function of the cellular membranes, which in turn could lead to leakage of solutes into the extracellular space resulting in BER (Ho and White 2005; Park et al. 2005; de Freitas et al. 2011b).

The majority of the cell wall $\mathrm{Ca}^{2+}$ is bound to the deesterified pectin whereas the remainder is in free form (Marschner 2011). Pectin is the major component of the middle lamellae in plants (Demarty et al. 1984; White and Broadley 2003; Marschner 2011) and is synthesized in the Golgi apparatus to be secreted into the cell wall in a highly methylesterified form (Goldberg et al. 1996; Micheli 2001; Wormit and Usadel 2018). During growth, the secreted pectin undergoes modifications by pectin methylesterases (PMEs) which is countered by pectin methylesterase inhibitors (Micheli 2001; Bosch et al. 2005; Pelloux et al. 2007; Palin and Geitmann 2012; Wormit and Usadel 2018). $\mathrm{Ca}^{2+}$ interacts electrostatically with the negatively charged carboxyl groups on the demethylated pectin facilitating the cross linking of the pectin molecules and stiffening of the cell wall (Micheli 2001; Wormit and Usadel 2018). Retaining the concentration of freely available apoplastic $\mathrm{Ca}^{2+}$ is critical to maintain membrane stability and for cellular responses to BER. The concentration of free apoplastic $\mathrm{Ca}^{2+}$ is dependent on pectin bound $\mathrm{Ca}^{2+}$ which is required for cell wall stability. Thus, when cell wall and membrane stability collapses, BER symptoms can be initiated in response to the stress (de Freitas et al. 2011b; Marschner 2011; Watanabe et al. 2021).

The suspected role of pectin in sequestering $\mathrm{Ca}^{2+}$ and causing BER has led to studies that aimed at modifying pectin properties. Using gene silencing, antisense expression of pectin methylesterase LePME3 (Solyc07g064190) increased water-soluble $\mathrm{Ca}^{2+}$ concentration in tomato fruits resulting in less electrolyte leakage and less BER (de Freitas et al. 2012b). Note however, that the antisense expression led to the downregulation of other PME genes as well, namely Solyc03g123630 (PMEU1), Solyc07g064170 (PE1), Solyc07g064180 (PME2.1), Solyc06g051960 (LES.9028) and Solyc03g083360 (Les.10790) (de Freitas et al. 2012b). The increase in soluble $\mathrm{Ca}^{2+}$ concentration in the antisense plants is particularly noticeable in the apoplast and is associated with the lack of cell plasmolysis compared to control. Moreover, the pectin in the antisense plants was highly methylated compared to control. In sum, the role of free apoplastic $\mathrm{Ca}^{2+}$ concentration maintains proper $\mathrm{Ca}^{2+}$ homeostasis among different cellular compartments and prevents membrane leakage, hence reduced BER incidence (de Freitas et al. 2012b). In addition, PMEs are critical in regulating pectin composition which is directly influencing BER (de Freitas et al. 2012b). Even though numerous studies have correlated BER to $\mathrm{Ca}^{2+}$ homeostasis (Geraldson 1956; Spurr 1959; Adams and Ho 1993; Bar-Tal et al. 2001; de Freitas et al. 2011b; de Freitas et al. 2012b), findings from other studies suggest that aberrant $\mathrm{Ca}^{2+}$ homeostasis is a consequence and may not be the cause of BER (Nonami et al. 1995; Saure 2001; Rached et al. 2018; Matsumoto et al. 2021). For example, before and right after the onset of BER, the $\mathrm{Ca}^{2+}$ concentration is the same among all the fruits for the different tissue types (Nonami et al. 1995). As BER is developing further, the $\mathrm{Ca}^{2+}$ concentrations start to differ markedly. It is perhaps the organization of the pectin structure in the middle lamellae that is crucial to regulating the onset of BER in plants.

\section{Reactive oxygen species (ROS) and BER}

$\mathrm{Ca}^{2+}$ and ROS signaling are both interrelated secondary messengers that respond to many environmental stresses. $\mathrm{Ca}^{2+}$ regulates ROS production, whereas ROS regulates $\mathrm{Ca}^{2+}$ homeostasis (Kobayashi et al. 2007; Jiang et al. 2011; Görlach et al. 2015). Whether ROS poses a threat to cells or has a role in response signaling depends on the equilibrium between ROS generation and detoxification (Sharma et al. 2012; Ayer et al. 2014). In plants, electron transport reactions in the plasma membrane (e.g. NADPH oxidase), the endoplasmic reticulum, the chloroplast and the mitochondria (e.g. the electron transport chain) are the major sources of ROS production (Trachootham et al. 2008). These sources produce free radicals such as superoxide anion, hydroxyl radicals as well as nonradical molecules like hydrogen peroxide and singlet oxygen (Sharma et al. 2012). Plant cells have evolved to alleviate the negative impacts of ROS by producing enzymatic and nonenzymatic antioxidants in the ROS scavenging pathway (Mittler 2002; Gratão et al. 2005). Enzymatic antioxidants consist of superoxide dismutase (SOD), ascorbate peroxidase (APX), monodehydroascorbate reductase (MDHAR), dehydroascorbate reductase (DHAR), glutathione reductase (GR), catalase (CAT), and others (Willekens et al. 1997; Trachootham et al. 2008; Marengo et al. 2016). The major nonenzymatic antioxidants include glutathione, ascorbate, as well as tocopherol, flavonoids, phenolic compounds, and carotenoids (Sies and Stahl 1995; Ayer et al. 2014). The Ascorbate-Glutathione pathway plays a significant role in detoxifying ROS in plants and consists of four main enzymes namely: APX, MDHAR, DHAR, and GR and two antioxidants: AsA and GSH (Noctor and Foyer 1998; Foyer and Noctor 2011).

Excessive ROS leading to lipid and protein oxidation, enzyme inhibition, and cell membrane leakage are all are 
associated with BER. Therefore, ROS is considered a critical component of BER onset and development (Dhindsa et al. 1981; Van Breusegem and Dat 2006; Sharma et al. 2012; de Freitas et al. 2018; Reitz and Mitcham 2021). Tomatoes grown under $\mathrm{Ca}^{2+}$-deficient conditions experience excess ROS accumulation and increased BER incidence that is associated with the upregulation of NADPH oxidase and SOD (Mestre et al. 2012). Similarly, peppers grown under saline conditions experience high ROS accumulation in the apoplast due to increased activity of NADPH oxidase activity (Aktas et al. 2005). On the other hand, many antioxidant genes such as $C A T, A P X$, and $G R$ are down-regulated in tomatoes grown under $\mathrm{Ca}^{2+}$ deficient conditions (Ming and Zhong-Guan 1995; Schmitz-Eiberger et al. 2002; Yang and Poovaiah 2002; Mestre et al. 2012). The tomato cultivar HM 4885, one of the preferred processing tomatoes in California, USA, experienced 85\% BER incidence that was attributed to the down regulation of $C A T$ leading to higher ROS accumulation (Reitz and Mitcham 2021). Consequently, the aberrant regulation of critical enzymes in the ROS detoxification pathway can lead to extensive $\mathrm{H}_{2} \mathrm{O}_{2}$ accumulation, lipid peroxidation and membrane breakdown, which subsequently results in increased BER incidence (Mestre et al. 2012).

Tomato varieties that have naturally high levels of ascorbate and antioxidants during the most sensitive stage of BER are more resistant to the disorder than those that have lower antioxidant levels, irrespective of the fruit $\mathrm{Ca}^{2+}$ concentration (Rached et al. 2018). Further, BER does not always consume the entire fruit (Fig. 2). This may be due to increased lignification, antioxidants, and oxidative stress-related proteins that inhibit further expansion of BER to the neighboring healthy tissues (Schmitz-Eiberger et al. 2002; Casado-Vela et al. 2005; Mestre et al. 2012; Reitz and Mitcham 2021).

Taken together, the ROS enzymes and antioxidants play a major role in BER development which is enhanced by insufficient $\mathrm{Ca}^{2+}$ concentration and abiotic stress (Noctor and Foyer 1998; Aloni et al. 2008; Rached et al. 2018). Specifically, the activation of enzymes in ROS production pathway as well as inhibition of enzymes in ROS scavenging pathway leads to membrane leakage and consequently higher BER incidence.

\section{Other physiological factors in BER development}

Certain nutrients have antagonistic effects on the uptake of each other. High concentrations of monovalent cations in soils, such as potassium $\left(\mathrm{K}^{+}\right)$, magnesium $\left(\mathrm{Mg}^{+}\right)$, sodium $\left(\mathrm{Na}^{+}\right)$and ammonium $\left(\mathrm{NH}_{4}{ }^{+}\right)$have a negative impact on the uptake of divalent cation $\mathrm{Ca}^{2+}$, thereby increasing BER incidence (Taylor and Locascio 2004; Mengel and Kirkby 2012). For instance, a rise in $\mathrm{NH}_{4}^{+}$ concentration in the nitrate/ammonium ratio suppressed the $\mathrm{Ca}^{2+}$ uptake and led to an increase in BER development (Geraldson 1956; Marti and Mills 1991; Nukaya et al. 1995; Bar-Tal et al. 2001; Taylor and Locascio 2004). The uptake of other elements such as boron $\left(\mathrm{B}^{+}\right)$ may also influence BER incidence. Fruits that were collected from a BER-resistant accession showed a high correlation between $\mathrm{B}^{+}$and $\mathrm{Ca}^{2+}$ concentration in the distal part of each fruit whereas the susceptible accession showed no correlation between the two elements (Watanabe et al. 2021). In this case, the link between $\mathrm{B}^{+}$and $\mathrm{Ca}^{2+}$ might reveal a role in stabilizing the pectin structures in the cell wall.

Plant growth regulators also affect BER development. The plant growth regulators auxin and gibberellin (GA) are reported to accelerate fruit growth and cause an increase in BER (de Freitas et al. 2012a; Gaion et al. 2019). The decreased $\mathrm{Ca}^{2+}$ concentration that was observed in the fruits upon the GA application was attributed to increased activity of $\mathrm{Ca}^{2+} / \mathrm{H}^{+}$exchangers and Ca-ATPase genes, that are responsible for $\mathrm{Ca}^{2+}$ transport into the storage organelles and the apoplastic space (de Freitas et al. 2012a). Specifically, GA application leads to the reduction of the apoplastic water-soluble $\mathrm{Ca}^{2+}$ content and enhanced cell membrane permeability (de Freitas, et al. 2012). Additionally, GA application leads to elevated ROS levels and decreased expression of many antioxidant genes such as APX, SOD, and CAT (Fath et al. 2001). On the other hand, application of growth retardants such as abscisic acid and Apogee (inhibitor of GA biosynthesis) to tomato plants showed reduced or no BER (de Freitas et al. 2011a; Barickman et al. 2014; de Freitas et al. 2014; de Freitas et al. 2018). Eliminating BER was attributed to the increased pericarp $\mathrm{Ca}^{2+}$ concentration and a higher number of functional xylem vessels in the placenta and pericarp tissues of fruits during the early growth stages (de Freitas et al. 2012a). These retardants also trigger antioxidant production to counter ROS activity, thereby further reducing BER incidence (de Freitas et al. 2018). Slower initial fruit growth rates are also associated with reduced BER incidence (Ho et al. 1987; Aktas et al. 2003; Aktas et al. 2005; Vinh et al. 2018; Watanabe et al. 2021). This suggests that the increased growth rate following pollination or after growth regulator application creates extensive stresses in the distal fruit part. This could lead to lower $\mathrm{Ca}^{2+}$ concentrations, and reduced cell wall stabilization and membrane integrity (Ikeda et al. 2017; Watanabe et al. 2021).

\section{Relationship between BER and fruit morphology}

Fruit size and BER onset are positively correlated to one another in tomato (Marcelis and Ho 1999; Heuvelink and Körner 2001) and no study has reported the occurrence of BER in wild relatives and small fruited varieties 
of tomato (Ho and White 2005). As BER is only observed in cultivated plants, domestication may have driven BER as a consequence of selections for larger produce. The tomato gene Cell Size Regulator (FW11.3/ CSR) increases fruit weight by increasing the cell size (Mu et al. 2017). FW11.3 near isogenic lines (NILs) that carry the derived allele of CSR showed significantly higher BER incidence compared to FW11.3 NILs that carry the wild type allele, indicating that FW11.3/CSR may have a role in BER development (Mu 2015). The association of BER with this fruit weight genes is likely indirect and not causative because many tomato varieties with the derived fruit weight alleles are resistant to BER.

In addition to fruit size, elongated fruit shapes are more prone to BER than the round-fruited varieties $(\mathrm{Ku}$ and Tanksley 1998; Ho and White 2005; Riboldi et al. 2018). Elongated fruit shape in tomato is controlled by only a handful of genes, namely SUN, OVATE, OFP2O and FS8.1 (Ku et al. 2000; Liu et al. 2002; Xiao et al. 2008; Sun et al. 2015; Wu et al. 2018). Among these genes, the round fruit allele of $f s 8.1$ is associated with low BER Incidence (Ku and Tanksley 1998). Moreover, the varieties San Marzano carrying the OVATE mutation and Banana Legs carrying the SUN mutation are highly susceptible to BER (Riboldi et al. 2018). Despite the demand for these produce shapes in the processing tomato industry, growers often avoid growing certain varieties due to potentially high yield losses. The likely mechanism of BER in elongated fruits has been proposed to be caused by the reduced functional xylem elements in the distal end of the fruit leading to reduced $\mathrm{Ca}^{2+}$ concentration compared to proximal end (Ho and White 2005; Riboldi et al. 2018).

\section{Genetic basis of BER}

In addition to the physiological factors, tomato varieties display varying degrees of BER which suggests a genetic basis to the disorder (Adams and Ho 1992; Ho et al. 1995; Ho and White 2005). The earliest investigation in the genetic basis of BER came from studies using tomato introgression lines (ILs). These ILs consist of genomic segments of Solanum pennellii LA716 introgressed into Solanum lycopersicum cv M82 (Eshed and Zamir 1995). Among these lines, IL8-3 features lower BER Incidence compared to the M82 parent (Uozumi et al. 2012; Ikeda et al. 2017; Watanabe et al. 2021). This region was fine mapped to $610 \mathrm{~kb}$ corresponding 78 genes (Uozumi et al. 2012; Ikeda et al. 2017). Because the higher $\mathrm{Ca}^{2+}$ concentration in the distal part of the fruit and the initial slower growth rate in the BER resistant line, the results indicate that IL8-3 might harbor gene(s) affecting $\mathrm{Ca}^{2+}$ concentration and growth rate in the early stages of fruit development. Additionally, further use of these IL8-3 lines revelated that many $\mathrm{Ca}^{2+}$-transport-related genes such as cation exchanger $(\mathrm{CAX}), \mathrm{Ca}^{2+}$-ATPase, $\mathrm{Ca}^{2+}$ channel and $\mathrm{Na}^{+} / \mathrm{Ca}^{2+}$ exchanger were differentially expressed between M82 and IL8-3 ten days after flowering but none of these genes mapped to location of IL83 on chr08 (Ikeda et al. 2016). These results may suggest that $\mathrm{Ca}^{2+}$-transport-related genes in other chromosomes are likely regulated by one of the 78 genes located in 610 $\mathrm{kbp}$ region in IL8-3. (Ikeda et al. 2017). Another IL, namely IL5-4, located on chr05 also featured differences in BER but in this case, the severity is higher in the IL than in the control M82 (Matsumoto et al. 2021). This locus has not been finemapped further.

Due to the low genetic diversity between closely related tomato accessions, the genetic basis of BER in populations derived from crosses among cultivars was hampered by the lack of molecular markers until recently. With the advent of the full genome sequence of tomato (Tomato Genome Consortium 2012), many resequencing projects enable the discovery of single nucleotide polymorphisms (SNPs) between closely related parents. Using the QTL seq approach, the enrichment of SNPs that are associated with the trait leads to the development of molecular markers to map BER loci in the population (Topcu et al. 2021). In populations derived from crosses between Solanum lycopersicum var. cerasiforme (SLC) and S. lycopersicum var. lycopersicum (SLL), four loci were identified: BER3.1 and BER3.2 on chr03, BER4.1 on chr04 and BER11.1 on chr11 (Topcu et al. 2021). BER3.2 and BER11.1 were further finemapped to 1.58 and $1.13 \mathrm{Mb}$ respectively, whereas BER11.1 was also mapped in another population derived from $S L L \mathrm{cv}$ Ailsa Craig and SLL cv Kentucky Beefsteak (Prinzenberg et al. 2021). The studies showed that BER3.2 is likely corresponding to the fruit weight gene FW3.2/KLUH which was segregating in one of the populations (Topcu et al. 2021) as larger fruit tend to be more susceptible to BER than smaller fruits (see above section). In sum, the studies into the genetic basis of BER identified a total of five loci in tomato namely: chr 03, chr 04, chr 05, chr 08 and chr 11 and excluding FW3.2/KLUH (Fig. 3). The cloning of the genes in these loci should provide novel insights into the onset and early developmental stages of BER.

\section{Conclusion and future perspectives}

The research on BER has led to the findings that the interplay of $\mathrm{Ca}^{2+}$ homeostasis and ROS accumulation perform critical roles in the development of the disorder. Together, they affect membrane stability and cell wall properties as to the degree of pectin methylation and hence BER appearance. Because the combination of environmental stress and nutritional factors affect the incidence of BER greatly, this disorder is often difficult to manage in field and greenhouse growth conditions in many agricultural settings. Going forward, growers will 


Fig. 3 Location of the five BER loci in the tomato genome
BER3.1

need to remain vigilant and pursue proper field management practices such as mulching, effective water drainage, proper irrigation systems, balanced fertilizer applications, and soil reclamation, which is the removal of salt from the root zone (Machado and Serralheiro 2017; Hagassou et al. 2019). Other management strategies such as the use of growth retardants can also help alleviate BER symptoms, but these are only available to commercial growers. On the other hand, a stronger emphasis on harnessing the power of the genetic variation in crop germplasm to at least reduce BER is critical. For example, a focus on the increased production of antioxidants in breeding programs should ameliorate the incidence and severity of BER. These high antioxidant-producing accessions would prevent lipid and protein oxidation, membrane breakdown, cell plasmolysis and hence BER. Another focus in breeding programs should be on vegetable varieties that feature a slower growth rate following pollination to avoid developing BER. As the genetic studies start to shed light on the causal genes underlying BER, new solutions to crop improvement in many vegetables are possible. For example, down regulation or knock outs of BER susceptibility genes using CRISPR-Cas gene and/or promoter editing should lead to the development of more resistant commercially produced varieties. Therefore, the toolkit to improve BER is expected to expand with new means for breeders to develop varieties that are more resistant to this oftendevastating physiological disorder.

\footnotetext{
Abbreviations

ABA: Abscisic acid; $\mathrm{NH}_{4}^{+}$: Ammonium; APX: Ascorbate peroxidase; BER: Blossom-end rot; $\mathrm{B}^{+}$: Boron; $\mathrm{Ca}^{2+}$ : Calcium; CAT: Catalase; CAX: Cation exchanger; CSR: Cell Size Regulator; DHAR: Dehydroascorbate reductase; GA: Gibberellic acid; GR: Glutathione reductase; ILs: Introgression lines; $\mathrm{Mg}^{+}$: Magnesium; MDHAR: Monodehydroascorbate reductase; NILs: Near isogenic lines; PMEs: Pectin methylesterases; $\mathrm{K}^{+}$: Potassium; ROS: Reactive Oxygen Species; SLL: S. lycopersicum var. lycopersicum; SNPS: Single nucleotide polymorphisms; $\mathrm{Na}^{+}$: Sodium; SLC: Solanum lycopersicum var. cerasiforme; SOD: Superoxide dismutase
}

Acknowledgements

We thank the members of the van der Knaap and Nambeesan lab for helpful discussions on the research reviewed in this study.

\section{Authors' contributions}

YT drafted the manuscript, SUN and EvdK conceived the idea and acquired funding, EvdK and SUN revised the manuscript. All authors approve the submitted version and are accountable for the accuracy and integrity of any part of the research.

\section{Funding}

The research in the van der Knaap and Nambeesan labs on BER is funded by USDA NIFA AFRI grant number 2020-67013-30912. Yasin Topcu is

acknowledging funding by the Ministry of National Education of Turkey for a graduate fellowship as well as the John Ingle Innovation in Plant Breeding Award.

\section{Availability of data and materials}

Not applicable.

\section{Declarations}

Ethics approval and consent to participate Not applicable.

\section{Consent for publication}

Not applicable.

\section{Competing interests}

The authors declare that they have no competing interests.

Received: 20 October 2021 Accepted: 16 December 2021 Published online: 12 January 2022

\section{References}

Adams P, Ho LC. The susceptibility of modern tomato cultivars to blossom-end rot in relation to salinity. Hortic Sci. 1992;67(6):827-39. https://doi.org/10.1 080/00221589.1992.11516315.

Adams P, Ho LC. Effects of environment on the uptake and distribution of calcium in tomato and on the incidence of blossom-end rot. Plant Soil. 1993. 154(1):127-32. https://doi.org/10.1007/BF00011081.

Aktas H, Karni L, Aloni B, Bar-Tal A. Physiological and biochemical mechanisms leading to blossom-end rot in greenhouse-grown peppers, irrigated with saline solution. Acta Hortic. 2003;(609):81-8. https://doi.org/10.17660/Acta Hortic.2003.609.9

Aktas H, Karni L, Chang D-C, Turhan E, Bar-Tal A, Aloni B. The suppression of salinity-associated oxygen radicals production, in pepper (Capsicum annuum) fruit, by manganese, zinc and calcium in relation to its sensitivity to blossomend rot. Physiol Plant. 2005;123(1):67-74. https://doi.org/10.1111/j.1399-3054.2 004.00435.x. 
Aloni B, Karni L, Deventurero G, Turhan E, Aktas H. Changes in ascorbic acid concentration, ascorbate oxidase activity, and apoplastic $\mathrm{pH}$ in relation to fruit development in pepper (Capsicum annuum L.) and the occurrence of blossom-end rot. J Hortic Sci Biotechnol. 2008. https://doi.org/10.1080/1462 0316.2008.11512353.

Ayer A, Gourlay CW, Dawes IW. Cellular redox homeostasis, reactive oxygen species and replicative ageing in Saccharomyces cerevisiae. FEMS Yeast Res. 2014;14(1):60-72. https://doi.org/10.1111/1567-1364.12114.

Bangerth F. Calcium-related physiological disorders of plants. Annu Rev Phytopathol. 1979;17(1):97-122. https://doi.org/10.1146/annurev.py.17.090179. 000525.

Barickman TC, Kopsell DA, Sams CE. Foliar applications of abscisic acid decrease the incidence of blossom-end rot in tomato fruit. Sci Hortic. 2014;179:356-62. https://doi.org/10.1016/j.scienta.2014.10.004

Barta DJ, Tibbitts TW. Calcium localization and Tipburn development in lettuce leaves during early enlargement. J Am Soc Hortic Sci. 2000;125(3):294-8. https://doi.org/10.21273/JASHS.125.3.294.

Bar-Tal A, Aloni B, Karni L, Oserovitz J, Hazan A, Itach M, et al. Nitrogen nutrition of greenhouse pepper. I. Effects of nitrogen concentration and $\mathrm{NO}_{3}: \mathrm{NH}_{4}$ ratio on yield, fruit shape, and the incidence of Blossom-end rot in relation to plant mineral composition. HortScience. 2001. https://doi.org/10.21273/ HORTSCI.36.7.1244.

Bianco MS, Cecílio Filho AB, de Carvalho LB. Nutritional status of the cauliflower cultivar 'Verona' grown with omission of out added macronutrients. PLoS ONE. 2015;10(4):e0123500. https://doi.org/10.1371/journal.pone.0123500.

Bosch M, Cheung AY, Hepler PK. Pectin methylesterase, a regulator of pollen tube growth. Plant Physiol. 2005;138(3):1334-46. https://doi.org/10.1104/pp.1 05.059865 .

Bouzo C, Pilatti R, Favaro J. Control of blackheart in the celery (Apium graveolens L.) crop. J Agric Soc Sci. 2007;3:73-4.

Brust Gerald. Physiological tomato fruit disorders. 2021. https://extension.umd edu/resource/physiological-tomato-fruit-disorders. Accessed 11 Sep 2021.

Casado-Vela J, Sellés S, Bru MR. Proteomic approach to blossom-end rot in tomato fruits (Lycopersicon esculentum M.): Antioxidant enzymes and the pentose phosphate pathway. Proteomics. 2005. https://doi.org/10.1002/ pmic.200401146.

Chamberlain E. Blossom-end rot of tomatoes. NZ J Agric. 1933;46:293-6.

Clapham DE. Calcium signaling. Cell. 2007;131(6):1047-58. https://doi.org/10.101 6/j.cell.2007.11.028.

Clarkson DT, Mansfield TA, Davies WJ, Leigh RA. Roots and the delivery of solutes to the xylem. Philos Trans R Soc Lond Ser B Biol Sci. 1993;341(1295):5-17. https://doi.org/10.1098/rstb.1993.0086.

de Freitas ST. Amarante CVTd. Mitcham EJ. Cellular approach to understand bitter pit development in apple fruit. Postharvest Biol Technol: Labavitch JM; 2010. https://doi.org/10.1016/j.postharvbio.2010.02.006.

de Freitas ST, Jiang C-Z, Mitcham EJ. Mechanisms involved in calcium deficiency development in tomato fruit in response to gibberellins. J Plant Growth Regul. 2012a;31(2):221-34. https://doi.org/10.1007/s00344-011-9233-9.

de Freitas ST, Handa AK, Wu Q, Park S, Mitcham EJ. Role of pectin methylesterases in cellular calcium distribution and blossom-end rot development in tomato fruit. Plant J. 2012b;71(5):824-35. https://doi.org/1 0.1111/j.1365-313X.2012.05034.X.

de Freitas ST, Martinelli F, Feng B, Reitz NF, Mitcham EJ. Transcriptome approach to understand the potential mechanisms inhibiting or triggering blossomend rot development in tomato fruit in response to plant growth regulators. J Plant Growth Regul. 2018;37(1):183-98. https://doi.org/10.1007/s00344-0179718-2.

de Freitas ST, McElrone AJ, Shackel KA, Mitcham EJ. Calcium partitioning and allocation and blossom-end rot development in tomato plants in response to whole-plant and fruit-specific abscisic acid treatments. J Exp Bot. 2014; 65(1):235-47. https://doi.org/10.1093/jxb/ert364.

de Freitas ST, Shackel KA, Mitcham EJ. Abscisic acid triggers whole-plant and fruit-specific mechanisms to increase fruit calcium uptake and prevent blossom end rot development in tomato fruit. J Exp Bot. 2011a;62(8):264556. https://doi.org/10.1093/jxb/erq430.

de Freitas ST, Padda M, Wu Q, Park S, Mitcham EJ. Dynamic alternations in cellular and molecular components during blossom-end rot development in tomatoes expressing sCAX1, a constitutively active $\mathrm{Ca}^{2+} / \mathrm{H}^{+}$antiporter from Arabidopsis. Plant Physiol. 2011b;156(2):844-55. https://doi.org/10.1104/ pp.111.175208.
Demarty M, Morvan C, Thellier M. Calcium and the cell wall. Plant Cell Environ. 1984;7(6):441-8. https://doi.org/10.1111/j.1365-3040.1984.tb01434.x.

Dhindsa RS, Plumb-Dhindsa P, Thorpe TA. Leaf senescence: correlated with increased levels of membrane permeability and lipid peroxidation, and decreased levels of superoxide dismutase and catalase. J Exp Bot. 1981;32(1): 93-101. https://doi.org/10.1093/jxb/32.1.93.

Díaz-Pérez JC, Hook JE. Plastic-mulched bell pepper (Capsicum annuum I.) plant growth and fruit yield and quality as influenced by irrigation rate and calcium fertilization. HortScience. 2017. https://doi.org/10.21273/hortsci1183 $0-17$.

Eshed Y, Zamir D. An introgression line population of Lycopersicon pennellii in the cultivated tomato enables the identification and fine mapping of yieldassociated QTL. Genetics. 1995;141(3):1147-62. https://doi.org/10.1093/ genetics/141.3.1147.

Fath A, Bethke PC, Jones RL. Enzymes that scavenge reactive oxygen species are down-regulated prior to gibberellic acid-induced programmed cell death in barley aleurone. Plant Physiol. 2001. https://doi.org/10.1104/pp.126.1.156.

Foyer $\mathrm{CH}$, Noctor G. Ascorbate and glutathione: the heart of the redox hub. Plant Physiol. 2011;155(1):2-18. https://doi.org/10.1104/pp.110.167569.

Franco J, Bañón S, Madrid R. Effects of a protein hydrolysate applied by fertigation on the effectiveness of calcium as a corrector of blossom-end rot in tomato cultivated under saline conditions. Sci Hortic. 1994;57(4):283-92. https://doi.org/10.1016/0304-4238(94)90111-2.

Francois LE, Donovan TJ, Maas EV. Calcium deficiency of artichoke buds in relation to salinity. HortScience. 1991;26(5):549-53. https://doi.org/10.21273/ HORTSCI.26.5.549.

Gaion LA, Muniz JC, Barreto RF, D'Amico-Damião V, de Mello PR, Carvalho RF. Amplification of gibberellins response in tomato modulates calcium metabolism and blossom end rot occurrence. Sci Hortic. 2019;246:498-505 https://doi.org/10.1016/j.scienta.2018.11.032.

Geraldson C. The cause and control of black-heart of celery. Florida: Gainsville; 1952.

Geraldson C. Evaluation of control methods for blackheart of celery and blossomend rot of tomatoes. In Proc Fla State Hort Soc. 1956;69:236-41.

Goldberg R, Morvan C, Jauneau A, Jarvis MC. Methyl-esterification, deesterification and gelation of pectins in the primary cell wall. Biotechnol Prog. 1996. https://doi.org/10.1016/S0921-0423(96)80253-X.

Görlach A, Bertram K, Hudecova S, Krizanova O. Calcium and ROS: a mutual interplay. Redox Biol. 2015;6:260-71. https://doi.org/10.1016/j.redox.2015.08.010.

Gratão PL, Polle A, Lea PJ, Azevedo RA. Making the life of heavy metal-stressed plants a little easier. Funct Plant Biol. 2005;32(6):481-94. https://doi.org/10.1 071/FP05016.

Hagassou D, Francia E, Ronga D, Buti M. Blossom end-rot in tomato (Solanum lycopersicum L.): A multi-disciplinary overview of inducing factors and control strategies. Sci Hortic. 2019. https://doi.org/10.1016/j.scienta.2019.01.042.

Hepler PK, Winship LJ. Calcium at the cell wall-cytoplast interface. J Integr Plant Biol. 2010;52(2):147-60. https://doi.org/10.1111/j.1744-7909.2010.00923.x.

Heuvelink E, Körner O. Parthenocarpic fruit growth reduces yield fluctuation and blossom-end rot in sweet pepper. Ann Bot. 2001;88(1):69-74. https://doi. org/10.1006/anbo.2001.1427.

Ho L, Grange R, Picken A. An analysis of the accumulation of water and dry matter in tomato fruit. Plant Cell Environ. 1987. https://doi.org/10.1111/13 65-3040.ep11602110.

Ho LC, Adams P, Li XZ, Shen H, Andrews J, Xu ZH. Responses of ca-efficient and ca-inefficient tomato cultivars to salinity in plant growth, calcium accumulation and blossom-end rot. Hortic Sci. 1995;70(6):909-18. https://doi. org/10.1080/14620316.1995.11515366.

Ho LC, White PJ. A cellular hypothesis for the induction of blossom-end rot in tomato fruit. Ann Bot. 2005;95(4):571-81. https://doi.org/10.1093/aob/mci065.

Hochmuth GJ, Hochmuth RC. In: Soil and Water Science Department, Florida Cooperative Extension Service, Institute of Food and Agricultural Sciences, University of Florida, editor. Blossom-end rot in bell pepper: causes and prevention, vol. 2009. 2009. p. 1-5.

Hoegh-Guldberg O, Jacob D, Taylor M, Bindi M, Brown S, Camilloni I, et al. Impacts of $1.5^{\circ} \mathrm{C}$ global warming on natural and human systems. In: MassonDelmotte V, Zhai P, Pörtner H-O, Roberts D, Skea J, Shukla PR, et al. Global warming of $1.5^{\circ} \mathrm{C}$. IPCC Secretariat; 2018. 175-311.

Ikeda $\mathrm{H}$, Kanayama $\mathrm{Y}$, Blossom-end rot in fruit vegetables. In: Kanayama $\mathrm{Y}$, Kochetov A, editors. Abiotic stress biology in horticultural plants. Tokyo: Springer Japan; 2015. 117-26. https://doi.org/10.1007/978-4-431-55251-2_9. 
Ikeda H, Shibuya T, Imanishi S, Aso H, Nishiyama M, Kanayama Y. Dynamic metabolic regulation by a chromosome segment from a wild relative during fruit development in a tomato introgression line, IL8-3. Plant Cell Physiol. 2016;57(6):1257-70. https://doi.org/10.1093/pcp/pcw075.

Ikeda H, Shibuya T, Nishiyama M, Nakata Y, Kanayama Y. Physiological mechanisms accounting for the lower incidence of blossom-end rot in tomato introgression line IL8-3 fruit. Hort J. 2017;86(3):327-33. https://doi. org/10.2503/hortj.OKD-015.

Jiang F, Zhang Y, Dusting GJ. NADPH oxidase-mediated redox signaling: roles in cellular stress response, stress tolerance, and tissue repair. Pharmacol Rev. 2011;63(1):218-42. https://doi.org/10.1124/pr.110.002980.

Kobayashi M, Ohura I, Kawakita K, Yokota N, Fujiwara M, Shimamoto K, et al. Calcium-dependent protein kinases regulate the production of reactive oxygen species by potato NADPH oxidase. Plant Cell. 2007;19(3):1065-80. https://doi.org/10.1105/tpc.106.048884.

$\mathrm{Ku} \mathrm{H}$, Tanksley S, Round fruit allele of $\mathrm{fs}_{8.1} 1$ is associated with reduced incidence of blossom-end rot in tomato fruit. In: Fulton TM, editor. Report of the Tomato Genetics Cooperative. Ithaca: Cornell University; 1998. p. 28-9.

$\mathrm{Ku} \mathrm{H}-\mathrm{M}$, Grandillo S, Tanksley S. fs8.1, a major QTL, sets the pattern of tomato carpel shape well before anthesis. Theor Appl Genet. 2000;101(5-6):873-8. https://doi.org/10.1007/s001220051555.

Kudla J, Batistič O, Hashimoto K. Calcium signals: the lead currency of plant information processing. Plant Cell. 2010;22(3):541-63. https://doi.org/10.1105/ tpc.109.072686

Kuo CG, Tsay JS, Tsai CL, Chen RJ. Tipburn of Chinese cabbage in relation to calcium nutrition and distribution. Sci Hortic. 1981;14(2):131-8. https://doi. org/10.1016/0304-4238(81)90004-2.

Liu J, Van Eck J, Cong B, Tanksley SD. A new class of regulatory genes underlying the cause of pear-shaped tomato fruit. Proc Natl Acad Sci U S A. 2002;99(20): 13302-6. https://doi.org/10.1073/pnas.162485999.

Lobell DB, Hammer GL, McLean G, Messina C, Roberts MJ, Schlenker W. The critical role of extreme heat for maize production in the United States. Nat Clim Chang. 2013;3(5):497-501. https://doi.org/10.1038/nclimate1832.

Machado RMA, Serralheiro RP. Soil salinity: effect on vegetable crop growth. Management practices to prevent and mitigate soil salinization. Horticulturae. 2017. https://doi.org/10.3390/horticulturae3020030.

Macias-González M, Truco MJ, Bertier LD, Jenni S, Simko I, Hayes RJ, et al. Genetic architecture of tipburn resistance in lettuce. Theor Appl Genet. 2019;132(8): 2209-22. https://doi.org/10.1007/s00122-019-03349-6.

Marcelis LFM, Ho LC. Blossom-end rot in relation to growth rate and calcium content in fruits of sweet pepper (Capsicum annuum L.). J Exp Bot. 1999. https://doi.org/10.1093/jxb/50.332.357.

Marengo B, Nitti M, Furfaro AL, Colla R, Ciucis CD, Marinari UM, et al. Redox homeostasis and cellular antioxidant systems: crucial players in cancer growth and therapy. Oxidative Med Cell Longev. 2016;2016:1-16. https://doi. org/10.1155/2016/6235641.

Marschner H. Marschner's mineral nutrition of higher plants. 3rd ed. London: Academic press; 2011

Marti HR, Mills HA. Calcium uptake and concentration in bell pepper plants as influenced by nitrogen form and stages of development. J Plant Nutr. 1991; 14(11):1177-85. https://doi.org/10.1080/01904169109364276.

Matsumoto C, Yada H, Hayakawa C, Hoshino K, Hirai H, Kato K, et al. Physiological characterization of tomato introgression line IL5-4 that increases brix and blossom-end rot in ripening fruit. Hort J. 2021;90(2):215-22. https://doi.org/1 0.2503/hortj.UTD-264

Mengel K, Kirkby EA. Principles of plant nutrition. 5th. Dordrecht: Springer; 2012.

Mestre TC, Garcia-Sanchez F, Rubio F, Martinez V, Rivero RM. Glutathione homeostasis as an important and novel factor controlling blossom-end rot development in calcium-deficient tomato fruits. J Plant Physiol. 2012;169(17): 1719-27. https://doi.org/10.1016/j.jplph.2012.07.013.

Micheli F. Pectin methylesterases: cell wall enzymes with important roles in plant physiology. Trends Plant Sci. 2001;6(9):414-9. https://doi.org/10.1016/s13 60-1385(01)02045-3.

Ming G, Zhong-Guan L. Calmodulin-binding proteins from Zea mays germs. Phytochemistry. 1995;40(5):1335-9. https:/doi.org/10.1016/0031-9422(95)00381-G.

Mittler R. Oxidative stress, antioxidants and stress tolerance. Trends Plant Sci. 2002;7(9):405-10. https://doi.org/10.1016/S1360-1385(02)02312-9.

Motha RP, Baier W. Impacts of present and future climate change and climate variability on agriculture in the temperate regions: North America. Clim Chang. 2005;70(1-2):137-64. https://doi.org/10.1007/s10584-005-5940-1.
Mu Q. The cloning and cellular basis of a novel tomato fruit weight gene: Cell Size Regulator FW11.3/CSR): Dissertation (The Ohio State University); 2015. https://etd.ohiolink.edu/apexprod/rws_olink/r/1501/10?clear=10\&p10_a ccession_num=osu1437584743.

Mu Q, Huang Z, Chakrabarti M, Illa-Berenguer E, Liu X, Wang Y, et al. Fruit weight is controlled by cell size regulator encoding a novel protein that is expressed in maturing tomato fruits. PLoS Genet. 2017;13(8):e1006930. https://doi.org/1 0.1371/journal.pgen.1006930.

Noctor G, Foyer CH. Ascorbate and glutathione: keeping active oxygen under control. Annu Rev Plant Physiol Plant Mol Biol. 1998;49(1):249-79. https://doi. org/10.1146/annurev.arplant.49.1.249.

Nonami H, Fukuyama T, Yamamoto M, Yang L, Hashimoto Y. Blossom-end rot of tomato plants may not be directly caused by calcium deficiency. Acta Hortic. 1995;(396):107-14. https://doi.org/10.17660/ActaHortic.1995.396.11.

Nukaya A, Goto K, H-g J, Kano A, Ohkawa K. Effect of $\mathrm{NH}_{4}-\mathrm{N}$ level in the nutrient solution on the incidence of Blossom-end rot and gold specks on tomato fruit grown in rockwool. Acta Hortic. 1995. https://doi.org/10.17660/Acta Hortic.1995.401.46.

Palin R, Geitmann A. The role of pectin in plant morphogenesis. Biosystems. 2012;109(3):397-402. https://doi.org/10.1016/j.biosystems.2012.04.006.

Park S, Cheng NH, Pittman JK, Yoo KS, Park J, Smith RH, et al. Increased calcium levels and prolonged shelf life in tomatoes expressing Arabidopsis $\mathrm{H}^{+} / \mathrm{Ca}^{2+}$ transporters. Plant Physiol. 2005;139(3):1194-206. https://doi.org/10.1104/pp.1 05.066266 .

Pelloux J, Rustérucci C, Mellerowicz EJ. New insights into pectin methylesterase structure and function. Trends in Plant Sci. 2007;12(6):267-77. https://doi. org/10.1016/j.tplants.2007.04.001.

Prinzenberg A, Hvd S, RGF V, Marcelis L, Heuvelink E, Schouten H. Genetic mapping of the tomato quality traits brix and Blossom-end rot under supplemental LED and HPS lighting conditions (Research Square [Preprint]. 07 Apr 2021 [cited 15 Aug 2021]. Available from: 2021. https://doi.org/10.212 03/rs.3.rs-387667/v1.

Rached M, Pierre B, Yves G, Matsukura C, Ariizumi T, Ezura H, et al. Differences in blossom-end rot resistance in tomato cultivars is associated with total ascorbate rather than calcium concentration in the distal end part of fruits per se. Hort J. 2018;87(3):372-81. https://doi.org/10.2503/hortj.OKD-150.

Reitz NF, Mitcham EJ. Lignification of tomato (Solanum lycopersicum) pericarp tissue during blossom-end rot development. Sci Hortic. 2021. https://doi. org/10.1016/j.scienta.2020.109759.

Riboldi LB, Araújo SHdC, de Freitas ST, Camargo e Castro PRd. Incidence of Blossom-end rot in elongated tomato fruit. Botany. 2018. https://doi.org/ 0.1139/cjb-2018-0021.

Rosen CJ. Leaf tipburn in cauliflower as affected by cultivar, calcium sprays, and nitrogen nutrition. HortScience. 1990;25(6):660-3. https://doi.org/10.21273/ HORTSCI.25.6.660.

Saure MC. Blossom-end rot of tomato (Lycopersicon esculentum Mill.) - a calcium- or a stress-related disorder. Sci Hortic. 2001. https://doi.org/10.1016/ S0304-4238(01)00227-8

Schmitz-Eiberger M, Haefs R, Noga G. Calcium deficiency - influence on the antioxidative defense system in tomato plants. J Plant Physiol. 2002;159(7): 733-42. https://doi.org/10.1078/0176-1617-0621.

Selby AD. Investigations of plant diseases in forcing house and garden. Ohio Agricultural Experimental Station Bulletin. 1896;73:241-2.

Sharma P, Jha AB, Dubey RS, Pessarakli M. Reactive oxygen species, oxidative damage, and antioxidative defense mechanism in plants under stressful conditions. J Bot. 2012;2012:1-26. https://doi.org/10.1155/2012/217037.

Shear C. Calcium-related disorders of fruits and vegetables. HortScience. 1975;10: 361-5.

Sies H, Stahl W. Vitamins E and C, beta-carotene, and other carotenoids as antioxidants. Am J Clin Nutr. 1995;62(6):1315S-21S. https://doi.org/10.1093/a $\mathrm{jcn} / 62.6 .1315 \mathrm{~S}$

Spurr A. Anatomical aspects of blossom-end rot in the tomato with special reference to calcium nutrition. Hilgardia. 1959;28(12):269-95. https://doi.org/1 0.3733 /hilg.v28n12p269.

Stuckey HP. Transmission of resistance and susceptibility to blossom-end rot in tomatoes. Experiment: Georgia Experiment Station; 1916.

Su T, Li P, Wang H, Wang W, Zhao X, Yu Y, et al. Natural variation in a calreticulin gene causes reduced resistance to $\mathrm{Ca}^{2+}$ deficiency-induced tipburn in Chinese cabbage (Brassica rapa ssp. pekinensis). Plant Cell Environ. 2019. https://doi.org/10.1111/pce.13612. 
Sun L, Rodriguez GR, Clevenger JP, Illa-Berenguer E, Lin J, Blakeslee JJ, et al. Candidate gene selection and detailed morphological evaluations of fs8.1, a quantitative trait locus controlling tomato fruit shape. J Exp Bot. 2015. https://doi.org/10.1093/jxb/erv361.

Taylor MD, Locascio SJ. Blossom-end rot: A calcium deficiency. J Plant Nutr. 2004; 27(1):123-39. https://doi.org/10.1081/PLN-120027551.

Thor K. Calcium-Nutrient and Messenger. Front Plant Sci. 2019;10. https://doi. org/10.3389/fpls.2019.00440.

Tomato Genome Consortium. The tomato genome sequence provides insights into fleshy fruit evolution. Nature. 2012. https://doi.org/10.1038/nature11119.

Topcu Y, Sapkota M, Illa-Berenguer E, Nambeesan SU, van der Knaap E. Identification of blossom-end rot loci using joint QTL-seq and linkage-based QTL mapping in tomato. Theor Appl Genet. 2021;134(9):2931-45. https://doi. org/10.1007/s00122-021-03869-0.

Trachootham D, Lu W, Ogasawara MA, Nilsa R-DV, Huang P. Redox regulation of cell survival. Antioxid Redox Signal. 2008;10(8):1343-74. https://doi.org/10.1 089/ars.2007.1957.

U.S. Environmental Protection Agency. Climate change indicators in the United States: Weather and climate. 2021. https://www.epa.gov/climate-indicators/ weather-climate. Accessed 29 Nov 2021.

U.S. Global Change Research Program. Global climate change impacts in the United States. New York: Cambridge University Press; 2009

UF/IFAS. Cucurbit diseases: Blossom end rot. 2021. https://plantpath.ifas.ufl.edu/uscout/cucurbit/blossom-end-rot.html. Accessed 2 Dec 2021.

University of Minnesota Extension. Eggplant: Spots or rot on fruit. 2021. https://a pps.extension.umn.edu/garden/diagnose/plant/vegetable/eggplant/ fruitspots.html. Accessed 2 Dec 2021

Uozumi A, Ikeda H, Hiraga M, Kanno H, Nanzyo M, Nishiyama M, et al. Tolerance to salt stress and blossom-end rot in an introgression line, IL8-3, of tomato. Sci Hort. 2012;138:1-6. https://doi.org/10.1016/j.scienta.2012.01.036.

Van Breusegem F, Dat JF. Reactive oxygen species in plant cell death. Plant Physiol. 2006. https://doi.org/10.1104/pp.106.078295.

Vinh TD, Yoshida Y, Ooyama M, Goto T, K-i Y, Tanaka Y. Comparative analysis on Blossom-end rot incidence in two tomato cultivars in relation to calcium nutrition and fruit growth. Hort J. 2018. https://doi.org/10.2503/horti.OKD-114.

Voyle G. Blossom end rot causes and cures in garden vegetables. 2021. https:// www.canr.msu.edu/news/blossom_end_rot_causes_and_cures_in_garden_ vegetables. Accessed 2 Dec 2021.

Watanabe T, Tomizaki R, Watanabe R, Maruyama H, Shinano T, Urayama M, et al. Ionomic differences between tomato introgression line IL8-3 and its parent cultivar M82 with different trends to the incidence of blossom-end rot. Sci Hortic. 2021;287:110266. https://doi.org/10.1016/j.scienta.2021.110266.

Wedgworth HH, Neal DC, Wallace JM. Wilt and blossom-end rot of the tomato. Mississippi Agric Exp Station Bull. 1927;247:1-18.

White PJ, Broadley MR. Calcium in plants. Ann Bot. 2003;92(4):487-511. https:// doi.org/10.1093/aob/mcg164.

Willekens H, Chamnongpol S, Davey M, Schraudner M, Langebartels C, Van Montagu $\mathrm{M}$, et al. Catalase is a sink for $\mathrm{H}_{2} \mathrm{O}_{2}$ and is indispensable for stress defence in C3 plants. EMBO J. 1997;16(16):4806-16. https://doi.org/10.1093/ emboj/16.16.4806.

Wormit A, Usadel B. The multifaceted role of pectin methylesterase inhibitors (PMEIs). Int J Mol Sci. 2018;19(10). https://doi.org/10.3390/ijms19102878.

WSU NWREC. Pepper blossom-end rot. 2021. https://mtvernon.wsu.edu/?not-found= mtvernon.wsu.edu\%2F\%3Fattachment_id\%3D6055. Accessed 2 Dec 2021.

Wu S, Zhang B, Keyhaninejad N, Rodríguez GR, Kim HJ, Chakrabarti M, et al. A common genetic mechanism underlies morphological diversity in fruits and other plant organs. Nat Commun. 2018;9(1):4734. https://doi.org/10.1038/ s41467-018-07216-8.

Wuebbles DJ, Fahey DW, Hibbard KA, Arnold JR, DeAngelo B, Doherty S, et al. Climate Science Special Report: Fourth National Climate Assessment. U.S.: Global Change Research Program; 2017. https://doi.org/10.7930/J0DJ5CTG.

Xiao H, Jiang N, Schaffner E, Stockinger EJ, Evd K. A retrotransposon-mediated gene duplication underlies morphological variation of tomato fruit. Science. 2008. https://doi.org/10.1126/science.1153040.

Yang T, Poovaiah BW. Hydrogen peroxide homeostasis: activation of plant catalase by calcium/calmodulin. Proc Natl Acad Sci U S A. 2002;99(6):4097102. https://doi.org/10.1073/pnas.052564899.

\section{Publisher's Note}

Springer Nature remains neutral with regard to jurisdictional claims in published maps and institutional affiliations.

Ready to submit your research? Choose BMC and benefit from:

- fast, convenient online submission

- thorough peer review by experienced researchers in your field

- rapid publication on acceptance

- support for research data, including large and complex data types

- gold Open Access which fosters wider collaboration and increased citations

- maximum visibility for your research: over $100 \mathrm{M}$ website views per year

At BMC, research is always in progress.

Learn more biomedcentral.com/submissions 